\title{
Development and validation of an HPLC method for the determination of epicatechin in Maytenus ilicifolia (Schrad.) Planch., Celastraceae
}

\author{
Gisely Cristiny Lopes, Andressa Blainski, Paulo Victor Pires dos Santos, \\ Maria Cristina Diciaula, João Carlos Palazzo de Mello
}

Universidade Estadual de Maringá, Departamento de Farmácia, Av. Colombo, 5790, 87020-900 Maringá-PR, Brazil.

\begin{abstract}
RESUMO: "Desenvolvimento e validação de um método de CLAE para a determinação da epicatequina em Maytenus ilicifolia (Schrad.) Planch., Celastraceae". Um método simples, reprodutível e eficiente de cromatografia líquida de alta eficiência (CLAE) foi desenvolvido. Água ( $0,05 \%$ TFA):acetonitrila ( $0,05 \%$ TFA) foi utilizado como fase móvel em um sistema de gradiente para a determinação da epicatequina (EP) em folhas de Maytenus ilicifolia (Schrad.) Planch., Celastraceae. A análise foi realizada utilizando coluna RP C-18 $(5 \mu \mathrm{m})$ como fase estacionária, com vazão de $0,8 \mathrm{~mL} / \mathrm{min}$, e comprimento de onda de $210 \mathrm{~nm}$ para a detecção e determinação. Os principais parâmetros de validação do método foram determinados. A curva analítica apresentouse linear no intervalo de 10-120 $\mu \mathrm{g} / \mathrm{mL}$ (EP). O coeficiente de correlação da análise de regressão linear foi de 0,9988, o limite de detecção e o limite de quantificação foram de 28,61 e 86,77 $\mu \mathrm{g} /$ $\mathrm{mL}$, respectivamente. O conteúdo do EP foi determinado com sucesso, com boa reprodutibilidade e recuperação. Recuperação da EP foi 99,32\%. O método foi aplicado com sucesso na determinação da epicatequina em folhas de M. ilicifolia. A avaliação interlaboratorial demonstrou a reprodutibilidade do método com desvio padrão relativo de $14,62 \%$.
\end{abstract}

Unitermos: Maytenus ilicifolia, CLAE, epicatequina, desenvolvimento de método analítico, controle de qualidade

\begin{abstract}
A simple, reproducible and efficient high-performance liquid chromatography (HPLC) method was developed. Water $(0.05 \%$ TFA):acetonitrile $(0.05 \%$ TFA) was used as the mobile phase in a gradient system for the determination of epicatechin (EP) in leaves of Maytenus ilicifolia (Schrad.) Planch. The analysis was performed using an RP C-18 column $(5 \mu \mathrm{m})$ as the stationary phase, with a flow rate of $0.8 \mathrm{~mL} / \mathrm{min}$, at a wavelength of $210 \mathrm{~nm}$ for detection and determination. The main validation parameters of the method were also determined. The calibration curve was found to be linear, with a range of $10-120 \mu \mathrm{g} / \mathrm{mL}$ (EP). The correlation coefficient of the linear regression analysis was within 0.9988 , and the detection and quantification limits were 28.61 and $86.77 \mu \mathrm{g} / \mathrm{mL}$, respectively. The content of EP was successfully determined, with satisfactory reproducibility and recovery. Recovery of the EP was $99.32 \%$. The method was successfully applied to the determination of epicatechin in leaves of M. ilicifolia. The interlaboratorial evaluation showed the reproducibility of the method with a relative standard deviation of $14.62 \%$.
\end{abstract}

Keywords: Maytenus ilicifolia, HPLC, epicatechin, analytical method development, quality control.

\section{INTRODUCTION}

Maytenus ilicifolia (Schrad.) Planch., Celastraceae, is the most studied species in the genus Maytenus. The species is popularly known in Brazil as "espinheira-santa", and its native range includes southern Brazil, Paraguay, Uruguay, northern Argentina (Nascimento et al., 2005), Chile, and Bolivia (Cordeiro et al., 1999). In popular medicine, it is used for the treatment of inflammation and gastric ulcers (Balbach, 1980; Cruz, 1982; Born, 2000), and as a contraceptive, emmenagogue and anticancer agent (Arenas \& Moreno Azorero, 1977). Flavonol glycosides (Tiberti et al., 2007; de Souza et al., 2009), condensed tannins (de Souza et al., 2008; Pessuto et al., 2009; Mossi et al., 2009) such as epicatechin and procyanidin B2, and triterpenes (Itokawa et al., 1991; Ohsaki et al., 2004; Mossi et al., 2009) have been isolated and identified from its extract. The hypotensive and 
vasorelaxant properties (Rattmann et al., 2006; Crestani et al., 2009), anti-ulcer (Queiroga et al., 2000; Tabach \& Oliveira, 2003; Baggio et al., 2007; Baggio et al., 2009), antinociceptive and anti-inflammatory (Jorge et al., 2004), cytotoxic (Shirota et al., 1994), antioxidant (Vellosa et al., 2006), antimutagenic (Melo et al., 2001), and contraceptive activity (Montanari et al., 1998; Montanari \& Bevilacqua, 2002) from the leaves and roots, crude extract and fractions were attributed to the presence of phenolic metabolites and triterpenes.

The Brazilian Drug Agency (National Agency of Sanitary Surveillance, ANVISA) has approved the usage and sale of phytomedicines from M. ilicifolia, which are standardized by their tannin contents for the treatment of gastric disorders. Many Brazilian pharmaceutical companies produce and market phytopharmaceuticals containing this drug. The availability of validated assay methods is an important part of the quality control of these products, and such assays are required by Brazilian health authorities for registration of phytomedicines.

Several methods have been reported for the determination of the quality of products from $M$. ilicifolia (Leite et al., 2001; Soares et al., 2004; Braga et al., 2005). Although these methods are efficient, there are several limitations that complicate their routine use. The development and validation of an efficient analytical method is an integral part of the quality control of the source material, in order to guarantee the safety and effectiveness of the resulting compound (Hefnawy et al., 2006).

Here, we report a sensitive HPLC determination method with UV detection, for the separation and quantitative analysis of epicatechin, the marker component of $M$. ilicifolia, to provide a scientific basis for quality control of extracts from its leaves. The method was validated according to regulation RE 899/2003 of the National Health Surveillance Agency, Brazil, ICH guidelines, 1996 and ISO 5725. The following validation characteristics were assessed: specificity, linearity, limit of detection and quantitation, accuracy, precision, robustness and inter-laboratory reproducibility.

\section{EXPERIMENTAL}

\section{Plant material}

Leaves of Maytenus ilicifolia (Schrad.) Planch., Celastraceae, were collected in May 2008 in the city of Maringá, State of Paraná, Brazil (S 2324'09.6"; W 5156' 27.6"; $500 \mathrm{~m}$ altitude; Garmin v.2.24). The species was identified by Prof. Dr. Maria Auxiliadora Milaneze Gutierre. Voucher specimens are deposited at the herbarium of the Department of Biology of the Universidade Estadual de Maringá under number HUEM 10.602 .

\section{Chemicals and reagents}

All reagents and solvents were analytical and HPLC grades, including ethyl acetate and trifluoroacetic acid (TFA) (Merck, Darmstadt, Germany). Ultra-pure water obtained using a Milli-Q ${ }^{\circledR}$ UF-Plus apparatus (Millipore, Bedford, USA) with conductivity of $18 \mathrm{~m} \Omega$ was used in all experiments. Epicatechin (Sigma, USA) of the highest grade (purity $>99.0 \%$ ) was used as the external standard.

\section{Instrumentation and chromatographic conditions}

The analyses were carried out using an HPLC system (Gilson, USA) consisting of a solvent delivery pump (Model 321), a variable wavelength UV/ VIS detector (Model 156), a manual injection valve (Rheodyne $^{\circledR}$, USA) with a $20 \mu \mathrm{L}$ loop, degasser (Model 184), thermostatted column compartment (Model 831). Data collection and analyses were performed using UniPoint $^{\mathrm{TM}}$ LC System Software (Gilson, Villiers-leBel, France). A gradient elution was performed on a Phenomenex ${ }^{\circledR}$ Gemini RP C-18 column $(250 \mathrm{~mm}$ x 4.6 $\mathrm{mm}$ ) (Phenomenex International, USA), $5 \mu \mathrm{m}$ particle size, Phenomenex ${ }^{\circledR}$ SecurityGuard ${ }^{\mathrm{TM}}$ (RP C-18 cartridge) (20 $\mathrm{mm} \times 4.6 \mathrm{~mm})$. The mobile phase consisted of water $(0.05 \% \mathrm{TFA})$ as solvent $\mathrm{A}$ and acetonitrile $(0.05 \% \mathrm{TFA})$ as solvent $\mathrm{B}$, and both were degassed and filtered through a $0.45 \mu \mathrm{m}$ pore size filter (Millipore, Bedford, USA). Separations were effected by a linear gradient as follows: $0 \min 18 \%$ B; $13 \min 25 \%$ B; $16 \min 34 \%$ B; $20 \min 42 \%$ B; 23 min $65 \%$ B; 25 min $18 \%$ B. The mobile phase flow rate was $0.8 \mathrm{~mL} / \mathrm{min}$ and the injection volume was 100 $\mu \mathrm{L}$. The chromatographic runs were carried out at $28^{\circ} \mathrm{C}$. UV detection was performed at $210 \mathrm{~nm}$.

For the determination of peak purity, the Varian ProStar module (Varian, Palo Alto, CA, USA) with ProStar 210 Solvent Delivery and a ProStar 335 HPLCDAD was used.

The statistical analyses of the data were performed by means of STATISTICA 7.0 Software (Statsoft Inc., Tulsa, OK, USA).

\section{Sample preparation and purification}

The pulverized leaves $(5 \mathrm{~g} ; 250 \mathrm{~mm})$ were weighed and refluxed for $15 \mathrm{~min}$ in $50 \mathrm{~mL}$ distilled water. The extract was allowed to cool to room temperature and then filtered under reduced pressure and extracted three times with $50 \mathrm{~mL}$ ethyl acetate in a $250 \mathrm{~mL}$ separation funnel. For complete separation of the phases, the extract was allowed to stand at $-18{ }^{\circ} \mathrm{C}$ (freezer) for $5 \mathrm{~min}$. The organic phases were combined and filtered under reduced pressure through filter paper containing $5 \mathrm{~g}$ of anhydrous $\mathrm{Na}_{2} \mathrm{SO}_{4}$. The organic phase was concentrated in a rotavapor under reduced pressure to obtain a residue 
(RES). The RES was resuspended in $5 \mathrm{~mL}$ methanol:water $(2: 8 ; \mathrm{v} / \mathrm{v})$ and then extracted with SPE C8 $(55 \mu \mathrm{m}, 70$ $\AA$ ), previously stored, for $100 \mathrm{~mL}$ (volumetric flask). The RES was eluated with $10 \mathrm{~mL}$ methanol:water $(2: 8 ; \mathrm{v} / \mathrm{v})$ in the same flask $(100 \mathrm{~mL})$, and the volume was completed (S1). S1 (5 mL) was transferred to a volumetric flask (25 $\mathrm{mL})$, and the volume was completed with methanol:water $(1: 1 ; \mathrm{v} / \mathrm{v})(\mathrm{S} 2) . \mathrm{S} 2$ was filtered through a $0.5 \mu \mathrm{m}$ pore size filter (Millipore, Bedford, USA) prior to injection $(20 \mu \mathrm{L}$ microsyringe).

\section{Preparation of standard solution}

An epicatechin reference standard stock solution of $400 \mu \mathrm{g} / \mathrm{mL}$ was prepared in methanol:water $(1: 1 ; \mathrm{v} / \mathrm{v})$. Calibration standard solutions at five levels were prepared by serially diluting the stock solution to concentrations of 10.00, 40.00, 70.00, 100.00 and 120.00 $\mu \mathrm{g} / \mathrm{mL}$. The samples were filtered through a $0.5 \mu \mathrm{m}$ membrane (Millipore, Bedford, USA) prior to injection. Each analysis was repeated five times, and the calibration curves were fitted by linear regression.

\section{Method validation}

Specificity

The specificity, defined as the ability of the method to measure the analyte accurately and specifically in the presence of components in the sample matrix, was determined by analysis of chromatograms of the standard solution and the sample solutions (SS). The Varian Prostar system (DAD detector) described above was employed.

\section{Linearity}

The linearity between peak area and concentration was analyzed using three calibration curves obtained on three different days with standard solutions of epicatechin at five different concentrations each, $10-120 \mu \mathrm{g} / \mathrm{mL}$ for epicatechin. The linearity of the SS was available separately; the concentration range was selected during the release studies. The data for peak area versus drug concentration were treated by linear regression analysis.

\section{Sensitivity}

The limit of detection ( $L O D)$ and the limit of quantitation $(L O Q)$ were determined from the calibration curves of the epicatechin standard. $L O D$ was calculated according to the expression $3 \sigma / \mathrm{S}$, where $\sigma$ is the standard deviation of the response and $\mathrm{S}$ is the slope of the calibration curve. $L O Q$ was established by using the expression 10 б/S (ICH, 1996).

\section{Accuracy}

The accuracy was evaluated by means of recovery assays carried out by adding known amounts of the epicatechin standard to the sample, before the extraction process, at three different levels, three solutions each in triplicate $(11 \%, 28 \%$ and $37 \%)$. The percent recovery was determined by comparing the results of the analyses of the fortified samples, with the nominal value by means of Student's t test and ANOVA.

\section{Precision}

The test of repeatability was carried out using three samples of the S2 with three determinations of each sample. The area of the peaks corresponding to the substance was determined at $210 \mathrm{~nm}$. Precision was expressed as the relative standard deviations (\% RSD) of the concentrations of epicatechin. The analysis of variance (ANOVA) was used for estimating the total variability of the analytical method. Precision was expressed as the relative standard deviation ( $\%$ RSD) of the concentration of epicatechin.

\section{Robustness}

Three sample solutions were prepared and analyzed under the established conditions and by changing the wavelength parameter from $210 \mathrm{~nm}$ to 212 nm (Ministério da Saúde, 2003).

\section{Reproducibility interlaboratory}

Three laboratories in the States of Paraná, Santa Catarina, and Rio Grande do Sul (Brazil) participated: Departamento de Farmácia, Universidade Estadual de Maringá, Paraná (organizer); Departamento de Produção de Matéria Prima, Universidade Federal do Rio Grande do Sul, Rio Grande do Sul; and Centro de Ciências da Saúde, Universidade do Vale do Itajaí, Santa Catarina. Each laboratory was asked to describe all of the steps used for HPLC analyses, and these data are shown in Table 1. The studies were organized and the protocols were set up according to the ISO 5725 standard to determine the repeatability and reproducibility of a measurement method.

\section{RESULTS AND DISCUSSION}

The HPLC method carried out in this study was aimed at developing a chromatographic system, capable of eluting and resolving phenolic compounds in crude plant materials. The preliminary investigations were directed toward evaluating the effect of various factors on the system. The factors assessed include the sample purification, detection wavelength, the type of column, 
and the composition of the mobile phase.

The elimination of high-molecular-weight phenolic compounds from the plant extract is critically important, because of the interaction of these compounds with the stationary phase. This interaction can seriously damage the analytical column, interfering with the chromatographic process. Currently, the most widely employed sample-preparation methodologies are solidphase extraction and liquid-liquid extraction. Therefore, in this study, the extraction of condensed tannins from $M$. ilicifolia was optimized by using a mixture of water:ethyl acetate. The utilization of the simple one-step liquid-liquid extraction method should completely extract the target constituents from the matrix. The extraction efficiency was evaluated by HPLC, and the results demonstrated the reliability of the process (Lopes et al., 2009a).

The chromatographic separations were performed on a $\mathrm{C}-18$ analytical column, according to published methods (Soares et al., 2004; Lopes et al., 2009b). To obtain good separation, acetonitrile-water and methanol-water containing acid were investigated as mobile phases. The effects of the composition and $\mathrm{pH}$ of the mobile phase on the retention time of the extract and standard solutions were investigated. The particular parameters examined were the percentage of acetonitrile, the purification of the extract, and the $\mathrm{pH}$ values of the mobile phase component. To obtain chromatograms with good resolution of adjacent peaks, different flow rates $(0.6,0.8$, and $0.9 \mathrm{~mL} / \mathrm{min})$ were also investigated. Flow rate is critical because it affects the peak symmetry parameters. The optimization of flow rate is critical, since the extent of longitudinal broadening is inversely related to the flow rate of the mobile phase. In cases of either high or low flow rates, an ideal Gaussian curve of the peak is not obtained, because the peak symmetry parameters are affected, i.e., the asymmetry factor deviates from unity (Spezi, 1990). Good separation was obtained by a flow rate of $0.8 \mathrm{~mL} / \mathrm{min}$. After testing several acidic extraction producers (data not shown), we determined that acetonitrile:TFA $0.05 \%$ and water:TFA $0.05 \%$ showed the best results, enabling the fastest separation (25 $\mathrm{min}$ ) and best resolution. Acetonitrile was used as the organic solvent because it provided better sensitivity and lower background noise than methanol. In developing the method, addition of TFA, which suppresses the ionization of phenol groups, to all the solvent systems led to better separation of the polyphenol compounds. Therefore, use of TFA is essential for complete separation.

The choice of detection wavelength is a crucial step in developing an efficient method. A UV detector was used in the current study. The spectra of all the main peaks were investigated by use of the diode-array detector, and $210 \mathrm{~nm}$ was selected as the detection wavelength to obtain a sufficiently large number of detectable peaks in the chromatograms. Fig. 1 shows the chromatogram of the sample solution at $210 \mathrm{~nm}$. Comparing the absorbances at the two wavelengths, the absorbances at $210 \mathrm{~nm}$ were higher than those at $280 \mathrm{~nm}$ for all compounds in the system (data not shown). Thus, chromatograms recorded at $210 \mathrm{~nm}$ showed considerable improvement in the signal-to-noise ratio. The resolution of the peak of epicatechin in the sample, after analysis of the chromatograms by means of a photodiode-array detector, indicated the specificity of the method. The UV spectra of the compound confirmed the absence of impurities, because these did not change between the beginning and end of elution.

The linearity of the HPLC method was investigated for epicatechin in the range 10.00-120.00 $\mu \mathrm{g} / \mathrm{mL}$ at five concentration levels. Epicatechin showed a retention time of $7 \mathrm{~min}$. Based on 1/x weighted linear regression analysis; the responses for the standard in related concentration ranges were linear. The calibration equation was $\mathrm{y}=885.51 \mathrm{x}+953.56\left(\mathrm{n}=5, \mathrm{r}^{2}=0.9988\right)$ for epicatechin. The RSDs of the slopes were $\leq 5 \%$ for the analyte $(\mathrm{n}=5)$. Table 2 shows the back-fit calculations for curve data for the standard used in the validation runs, as well as the precision and accuracy of the back-fit calculations.

The $L O D$, defined as the lowest absolute concentration of analyte in a sample that can be detected but not necessarily quantified under the stated experimental conditions, was $28.61 \mu \mathrm{g} / \mathrm{mL}$ for epicatechin. The $L O Q$, defined as the lowest concentration of analyte in a sample that can be quantitatively determined with acceptable precision and accuracy, was $86.77 \mu \mathrm{g} / \mathrm{mL}$ for epicatechin.

Accuracy was determined by analyzing a sample of known concentration and comparing the measured value with the true value, using the method of standard addition. Table 3 summarizes the results for accuracy, expressed as the percentage of recovery and relative standard deviation (RSD) for both approaches. The method showed good accuracy.

Table 1. Laboratories equipment and LC columns.

\begin{tabular}{ccccccccc}
\hline Laboratory & HPLC system & $V_{\text {inj }}(\mu \mathrm{L})$ & $T\left({ }^{\circ} \mathrm{C}\right)$ & LC column & $L(\mathrm{~mm})$ & i.d. $(\mathrm{mm})$ & $d_{\mathrm{p}}(\mu \mathrm{m})$ & Detector \\
\hline UEM & Gilson 321 & 20 & 28 & Phenomenex $^{\circledR}$ Gemini RP C-18 & 250 & 4.6 & 5 & UV \\
UFRGS & Waters 2695 & 20 & 20 & Phenomenex $^{\circledR}$ Luna RP C-18 & 250 & 4.6 & 5 & PDA 996 \\
UNIVALI & Shimadzu LC 10 VP & 20 & 30 & Phenomenex $^{\circledR}$ Luna RP C-18 & 250 & 4.6 & 5 & UV \\
\hline
\end{tabular}


Table 2. Curve parameter summary and back-calculated calibration curve concentrations for epicatechin.

\begin{tabular}{lccccc}
\hline \multicolumn{5}{c}{ Epicatechin concentration $(\mu \mathrm{g} / \mathrm{mL})$} \\
\hline Mean \pm S.D. & 10.0 & 40.0 & 70.0 & 100.0 & 120.0 \\
RSD $\%$ & $8.53 \pm 0.72$ & $42.30 \pm 0.41$ & $69.69 \pm 0.44$ & $99.60 \pm 0.6$ & $119.83 \pm 0.93$ \\
\hline
\end{tabular}

Mean \pm S.D. $(n=5) ; R S D \%=(($ S.D. $/$ mean $) \times 100)$.

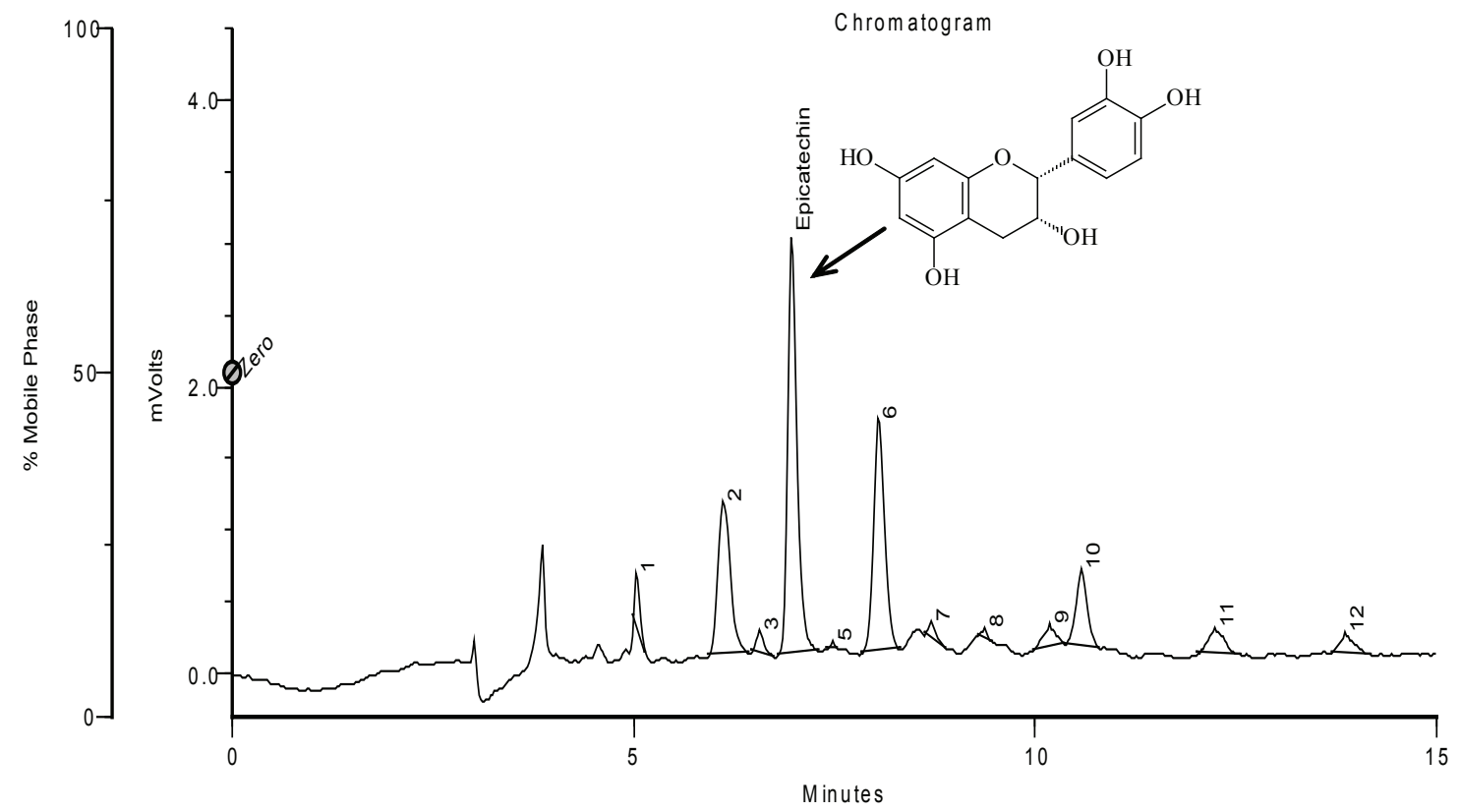

Figure 1. Chromatographic profile at $210 \mathrm{~nm}$ of the purified extract of Maytenus ilicifolia. Chromatographic conditions: column Phenomenex, Gemini C-18 (250 mm x $4.6 \mathrm{~mm}$ i.d., $5 \mu \mathrm{m})$, SecurityGuard (RP-cartridge) (20 mm x $4.6 \mathrm{~mm}$ i.d., $5 \mu \mathrm{m})$; mobile phase: water (TFA $0.05 \%$ ) A and acetonitrile (TFA $0.05 \%$ ) B: 0 min $18 \%$ B; $13 \min 25 \%$ B; 16 min 34\% B; 20 min $42 \%$ B; 23 min $65 \%$ B; $25 \mathrm{~min} 18 \% \mathrm{~B}$; flow-rate, $0.8 \mathrm{~mL} / \mathrm{min}$.

Table 3. Results of accuracy determination by analyzing of the epicatechin of known concentrations.

\begin{tabular}{|c|c|c|c|c|}
\hline $\begin{array}{c}\text { Theoretical } \\
\text { concentration } \mu \mathrm{g} / \mathrm{mL}\end{array}$ & $\begin{array}{l}\text { Amount recovered } \\
(\mu \mathrm{g} / \mathrm{mL})\end{array}$ & $\%$ Recovered & Mean (\%) & $\mathrm{RSD} \%$ \\
\hline \multirow{3}{*}{65.0} & 55.56 & 85.48 & \multirow{3}{*}{86.07} & \multirow{3}{*}{0.7} \\
\hline & 56.48 & 86.89 & & \\
\hline & 55.79 & 85.83 & & \\
\hline \multirow{3}{*}{80.0} & 81.86 & 102.32 & \multirow{3}{*}{102.31} & \multirow{3}{*}{0.6} \\
\hline & 82.45 & 103.06 & & \\
\hline & 81.25 & 101.56 & & \\
\hline \multirow{3}{*}{92.0} & 101.76 & 110.61 & \multirow{3}{*}{109.59} & \multirow{3}{*}{0.9} \\
\hline & 99.50 & 108.16 & & \\
\hline & 101.19 & 109.99 & & \\
\hline
\end{tabular}

Recovery interval stipulated by RE 899: 85-115\%; Mean \pm SD $(n=3) ;$ RSD $\%=(($ S.D. $/$ mean $) \times 100)$.

Table 4. Concentration of epicatechin $(\mu \mathrm{g} / \mathrm{mL})$ in Maytenus ilicifolia reference material (interlaboratorial study).

\begin{tabular}{cc}
\hline Laboratory & Concentration of epicatechin $[\overline{\boldsymbol{x}} \pm \boldsymbol{d} \boldsymbol{p}(\mathrm{CV} \%)]$ \\
\hline UEM & $58.98 \pm 1.05(1.78)$ \\
UFRGS & $59.94 \pm 1.23(2.06)$ \\
UNIVALI & $45.60 \pm 0.95(1.18)$ \\
\hline
\end{tabular}


The results obtained from the analyses of precision were $58.98 \pm 1.05 \mu \mathrm{g} / \mathrm{mL}(\mathrm{RSD} \%=1.78)$ for the replicas of the test. There were no significant differences between the assay results, indicating that the precision of the proposed method was good (RSD less than $2 \%$ ).

To ensure that the HPLC method is insensitive to minor changes in the experimental conditions, it is important to demonstrate the robustness of the method. When the wavelength was changed by $2 \mathrm{~nm}$, from 210 $\mathrm{nm}$ to $212 \mathrm{~nm}$, this alteration caused no significant change in the resolution of the epicatechin. This demonstrated the robustness of the method, under the conditions evaluated.

The organization of the inter-laboratory study results was planned to emphasize the comparison of the values obtained by the three participating laboratories, for the analysis of epicatechin in M. ilicifolia. In all the exercises, each laboratory performed six independent replicate determinations of epicatechin using the recommended analytical method. In addition, experiments on recovery, procedure blanks and detector linearity were carried out following a protocol discussed previously. The moisture content of the samples was determined for each sample and day using a sample intake not less than 1 g. Gravimetry was the method used for the determination of moisture, which was $10.13 \% \pm 0.25(\mathrm{RSD} \%=2.47)$.

The results from the inter-laboratory test are given in Table 4. The method is reproducible, since, through the inter-laboratory test, we obtained a relative standard deviation of $14.62 \%$. This value is lower than that recommended as a maximum limit of significance according to the Guide for Validation of Analytical and Bioanalytical Methods (RS 899/2003). Taking into account the results obtained in the inter-laboratory test, the common analytical procedure based on the method developed can be proposed as a recommended method for the analysis of epicatechin in a sample of M. ilicifolia.

\section{CONCLUSIONS}

We describe a rapid and robust HPLC assay for separation and quantitative analysis of epicatechin in Maytenus ilicifolia (Schrad.) Planch., Celastraceae. Efficient removal of interfering substances (condensed tannins of high molecular weight) was achieved by means of a liquid-liquid extraction. The clean-up of samples was very simple and demonstrated good efficiency. After the optimization of chromatographic conditions for determination of the epicatechin, the method was found to be specific and suitable for routine analysis because of its simplicity, sensitivity, accuracy and reproducibility, and it can be conveniently used for the analysis of epicatechin in M. ilicifolia.

\section{ACKNOWLEDGEMENTS}

The authors thank the Brazilian funding agencies Anvisa and Farmacopeia Brasileira. The study was funded by order \#001/2007-Anvisa, Farmacopeia Brasileira. Our gratitude to Profa. Dra. Amélia T. Henriques, Prof. Dr. José Ângelo S. Zuanazzi, Dra. Ana Lúcia Aboy, Profa. Dra. Tânia Mari Belle Bresolin and MSc.Luciana Cátia Block for their cooperation in the inter-laboratory study. Our gratitude to Dr. J. W. Reid for revising the English text.

\section{REFERENCES}

Arenas P, Moreno Azorero R 1977. Plants of common use in Paraguayan folk medicine for regulating fertility. Econ Bot 31: 298-301.

Baggio CH, Freitas CS, Mayer B, Dos Santos AC, Twardowschy A, Potrich FB, Cipriani TR, de Souza LM, Sassaki GL, Iacomini M, Marques MC, Mesia-Vela S 2009. Muscarinic-dependent inhibition of gastric emptying and intestinal motility by fractions of Maytenus ilicifolia Mart. ex Reissek. J Ethnopharmacol 123: 385-391.

Baggio CH, Freitas CS, Otofuji GM, Cipriani TR, Souza LM, Sassaki GL, Iacomini M, Marques MC, Mesia-Vela S. 2007. Flavonoid-rich fraction of Maytenus ilicifolia Mart. ex. Reiss protects the gastric mucosa of rodents through inhibition of both $\mathrm{H}+, \mathrm{K}+$-ATPase activity and formation of nitric oxide. J Ethnopharmacol 113: 433440.

Balbach A 1980. A Flora Nacional na Medicina Doméstica. São Paulo: A edificação do lar.

Born GCC 2000. Plantas medicinais da Mata Atlântica (Vale do Ribeira-SP). São Paulo, 289 p.Tese de Doutorado, Universidade de São Paulo.

Braga SM, de Medeiros FD, de Oliveira EJ, Macedo RO 2005. Development and validation of a method for the quantitative determination of aflatoxin contaminants in Maytenus ilicifolia by HPLC with fluorescence detection. Phytochem Anal 16: 267-271.

Cordeiro PJM, Vilegas JHY, Lanças FM 1999. HRGC-MS Analysis of terpenoids from Maytenus ilicifolia and Maytenus aquifolium (espinheira santa). J Braz Chem Soc 10: 523-526.

Crestani S, Rattmann YD, Cipriani TR, de Souza LM, Iacomini M, Kassuya CAL, Marques MCA, da Silva-Santos JE 2009. A potent and nitric oxide-dependent hypotensive effect induced in rats by semi-purified fractions from Maytenus ilicifolia. Vascul Pharmacol 51: 57-63.

Cruz GL 1982. Dicionário das plantas úteis do Brasil. São Paulo: Civilização Brasileira.

de Souza LM, Cipriani TR, Iacomini M, Gorin PAJ, Sassaki GL 2008. HPLC/ESI-MS and NMR analysis of flavonoids and tannins in bioactive extract from leaves of Maytenus ilicifolia. J Pharm Biomed Anal 47: 59-67.

de Souza LM, Cipriani TR, Sant'Ana CF, Iacomini M, Gorin PAJ, 
Sassaki GL 2009. Heart-cutting two-dimensional (size exclusion $\times$ reversed phase) liquid chromatographymass spectrometry analysis of flavonol glycosides from leaves of Maytenus ilicifolia. J Chromatogr A 1216: 99-105.

Hefnawy MM, Sultan MA, Al-Shehri MM 2006. Direct enantiomeric resolution of betaxolol with application to analysis of pharmaceutical products. Anal Chem Insights 1: 13-20.

ICH Topic Q2B 1996. Validation of Analytical Procedures: Methodology (CPMP/ICH/281/95), Step 4, Consensus Guideline, The European Agency for the Evaluation of Medicinal Products.

International Organisation for Standardisation (ISO) 1986. Precision of test methods determination of repeatability and reproducibility for a standard test method by interlaboratory tests, (ISO 5725), Geneva.

Itokawa $\mathrm{H}$, Shirota O, Ikuta H, Morita H, Takeya K, Iitaka Y 1991. Triterpenes from Maytenus ilicifolia. Phytochemistry 30: 3713-3716.

Jorge RM, Leite JPV, Oliveira AB, Tagliati CA 2004. Evaluation of antinociceptive, anti-inflammatory and antiulcerogenic activities of Maytenus ilicifolia. $J$ Ethnopharmacol 94: 93-100.

Leite JP, Rastrelli L, Romussi G, Oliveira AB, Vilegas JH, Vilegas W, Pizza C 2001. Isolation and HPLC quantitative analysis of flavonoid glycosides from Brazilian beverages (Maytenus ilicifolia and $M$. aquifolium). J Agric Food Chem 49: 3796-3801.

Lopes GC, Sanches ACC, Toledo CEM, Isler AC, Mello JCP 2009a. Determinação quantitativa de taninos em três espécies de Stryphnodendron por cromatografia líquida de alta eficiência. Rev Bras Cienc Farm 45:135-143.

Lopes GC, Bruschi ML, Mello JCP 2009b. RP-LC-UV Determination of proanthocyanidins in Guazuma ulmifolia. Chromatographia 69: 175-181.

Melo SF, Soares SF, Costa RF, Silva CR, Oliveira MBN, Bezerra RJAC, Caldeira-de-Araújo A, Bernardo-Filho M 2001. Effect of the Cymbopogon citratus, Maytenus ilicifolia and Baccharis genistelloides extracts against the stannous chloride oxidative damage in Escherichia coli. Mutat Res 496: 33-38.

Ministério da Saúde 2003. Resolução Específica (RE) 899 de 29 de maio de 2003, Agência Nacional de Vigilância Sanitária, Determina a publicação do Guia para validação de métodos analíticos e bioanalíticos, Diário Oficial da União.

Montanari T, Bevilacqua E 2002. Effect of Maytenus ilicifolia Mart. on pregnant mice. Contraception 65: 171-175.

Montanari T, Carvalho JE, Dolder H 1998. Effect of Maytenus ilicifolia Mart. ex. Reiss on spermatogenesis. Contraception 57: 335-339.

Mossi AJ, Mazutti M, Paroul N, Corazza ML, Dariva C, Cansian RL, Oliveira JV 2009. Chemical variation of tannins and triterpenes in Brazilian populations of Maytenus ilicifolia Mart. ex Reiss. Braz J Biol 69: 339-345.
Nascimento VT, Lacerda EU, Melo JG, Lima CSA, Amorim ELC, Albuquerque UP 2005. Controle de qualidade de produtos à base de plantas medicinais comercializados na cidade do Recife-PE: erva-doce (Pimpinella anisum L.), quebra-pedra (Phyllanthus spp.), espinheira santa (Maytenus ilicifolia Mart.) e camomila (Matricaria recutita L.). Rev Bras Pl Med 7: 56-64.

Ohsaki A, Imai Y, Naruse M, Ayabe S, Komiyama K, Takashima $\mathrm{J} 2004$. Four new triterpenoids from Maytenus ilicifolia. J Nat Prod 67: 469-471.

Pessuto MB, Costa IC, Souza AB, Nicoli FM, Petereit F, Luftmann H, Palazzo de Mello JC 2009. Atividade antioxidante de extratos e taninos condensados das folhas de Maytenus ilicifolia Mart. ex Reiss. Quim Nova 32: 412-416.

Queiroga CL, Silva GF, Dias PC, Possenti A, Carvalho JE 2000. Evaluation of the antiulcerogenic activity of friedelan$3 \beta$-ol and friedelin isolated from Maytenus ilicifolia (Celastraceae). J Ethnopharmacol 72: 465-468.

Rattmann YD, Cipriani TR, Sassaki GL, Iacomini M, Rieck L, Marques MCA, da Silva-Santos JE 2006. Nitric oxide-dependent vasorelaxation induced by extractive solutions and fractions of Maytenus ilicifolia Mart. ex Reissek (Celastraceae) leaves. J Ethnopharmacol 104: 328-335.

Shirota O, Morita H, Takeya K, Itokawa H 1994. Cytotoxic aromatic triterpenes from Maytenus ilicifolia and Maytenus chuchuhuasca. J Nat Prod 57: 1675-1681.

Soares LA, Oliveira AL, Ortega GG, Petrovick PR 2004. Development and validation of a LC-method for determination of catechin and epicatechin in aqueous extractives from leaves of Maytenus ilicifolia. J Pharm Biomed Anal 36: 787-790.

Spezi G 1990. HPLC in pharmaceutical analysis, vol. I, General Considerations, Boca Raton:CRC Press.

Tabach R, Oliveira WP 2003. Evaluation of the anti-ulcerogenic activity of a dry extract of Maytenus ilicifolia Martius ex Reiss produced by a jet spouted bed dryer. Pharmazie 58: 573-576.

Tiberti LA, Yariwake JH, Ndjoko K, Hostettmann K 2007. Identification of flavonols in leaves of Maytenus ilicifolia and M. aquifolium (Celastraceae) by LC/UV/ MS analysis. J Chromatogr B 846: 378-384.

Vellosa JCR, Khalil NM, Formenton VAF, Ximenes VF, Fonseca LM, Furlan M, Brunetti IL, Oliveira OMMF 2006. Antioxidant activity of Maytenus ilicifolia root bark. Fitoterapia 77: 243-244. 